LETTER TO JMG

\title{
Identification of novel locus for autosomal dominant butterfly shaped macular dystrophy on 5q21.2-q33.2
}

\author{
A I den Hollander, J J C van Lith-Verhoeven, F F J Kersten, J G A M Heister, C G F de Kovel, \\ A F Deutman, C B Hoyng, F P M Cremers
}

B utterfly shaped macular dystrophy was first described by Deutman et al. in 1970.' It is characterised by bilateral accumulation of pigmented or yellowish material at the level of the retinal pigment epithelium. Lesions consist of 3-5 "wings," which resemble the wings of a butterfly. Affected patients present with a subnormal electrooculogram and normal or slightly diminished visual acuity. The disease is relatively benign, but it can progress with age to chorioretinal atrophy in the parafoveal and peripapillary regions. ${ }^{2}$ Butterfly shaped macular dystrophy shares important similarities with age related macular degeneration-the most common cause of blindness in older patients. ${ }^{3}{ }^{4}$ In both diseases, abnormal deposition of lipofuscin like material at the level of the retinal pigment epithelium is found, which results in loss of the overlying photoreceptors. ${ }^{2}$

Butterfly shaped macular dystrophy has an autosomal dominant inheritance pattern. To date, it has been associated only with mutations in the peripherin/RDS gene. ${ }^{5-12}$ We ascertained members of the family with butterfly shaped macular dystrophy that was described originally by Deutman et al. in 1970, ${ }^{1}$ and we excluded peripherin/RDS as the causative gene in this family. ${ }^{2}$ In addition, we excluded the ROM-l gene; four genes expressed in cone photoreceptors; all known non-syndromic macular, retinal pigment epithelium, and choroidal dystrophy loci; all known Leber congenital amaurosis loci; and all known non-syndromic congenital and stationary retinal disease loci. ${ }^{2}$ This study aimed to identify the locus responsible for butterfly shaped macular dystrophy in this family with a genomewide linkage scan.

\section{PARTICIPANTS AND METHODS}

\section{Patients and ophthalmic examination}

We previously ascertained 13 members (eight affected and five unaffected) of a Dutch family with butterfly shaped macular dystrophy that was first described in 1970 by Deutman et al. ${ }^{12}$ Ophthalmic examination of the participating family members included best corrected Snellen visual acuity, slit lamp biomicroscopy, fundus examination, fluorescein angiography, electroretinography, electrooculography, colour vision, and dark adaptation testing. ${ }^{2}$

For this study, we ascertained and ophthalmologically examined eight additional family members. We obtained informed consent from all participating members. One member had a slightly diminished electrooculogram but a normal fundus appearance and therefore we excluded her from the study. For molecular analysis, we collected blood samples of all participating family members and isolated DNA by a standard extraction method. ${ }^{13}$

\section{Genotyping and linkage analysis}

We performed a genomewide linkage scan with 400 microsatellite markers distributed with an average spacing of $10 \mathrm{cM}$ in the human genome (ABI Prism Linkage Mapping Set MD-10 version 2.5; Applied Biosystems, Foster City, CA,

\section{Key points}

- Butterfly shaped macular dystrophy is an autosomal dominant eye disease characterised by bilateral accumulation of pigment in the macular area, which resembles the wings of a butterfly. To date, butterfly shaped macular dystrophy has been associated only with mutations in the peripherin/RDS gene.

- It was described originally in a Dutch family in 1970. We previously excluded the involvement of the peripherin/RDS gene, the ROM-1 gene, and 44 known loci involved in retinal dystrophies in this family. A genomewide linkage scan identified a novel locus for butterfly shaped macular dystrophy on chromosome $5 q 21.2-q 33.2$ between markers D5S433 and D5S487, with a maximum multipoint logarithm of odds score of 4.05 .

- The critical interval spans $46 \mathrm{cM}(52 \mathrm{Mb})$ and contains the gene that encodes the $\alpha$ subunit of cyclic guanosine $5^{\prime}$ monophosphate phosphodiesterase 6A (PDE6A). Sequence analysis of the PDE6A gene did not show a pathologic mutation.

USA). We typed fluorescently labelled markers on an ABI Prism 3100 genetic analyser (Applied Biosystems) with GeneMapper software (Applied Biosystems). We binned alleles with the Excel macro linkage designer developed by van Camp and coworkers, ${ }^{14}$ and we checked Mendelian inheritance of alleles with PedCheck software. ${ }^{15}$ We performed two point parametric linkage analysis of the genotyping data with the Linkage package ${ }^{16}$; we assumed an autosomal dominant mode of inheritance, with a disease allele frequency of 0.001 and a penetrance of 0.95 . We performed multipoint analysis for markers in the chromosome 5 interval (D5S644, D5S433, D5S2027, D5S471, D5S2115, D5S436, and D5S410) with Linkmap. ${ }^{16}$

We chose additional microsatellite markers for finemapping from the Marshfield and Généthon databases. ${ }^{17}{ }^{18}$ We subjected samples to polymerase chain reaction (PCR) amplification with a standard cycling profile of 34 cycles at $94^{\circ} \mathrm{C}$ for 1 minute, $55^{\circ} \mathrm{C}$ for 2 minutes, and $72^{\circ} \mathrm{C}$ for 1 minute. We labelled PCR products by incorporating $\alpha\left[{ }^{32} \mathrm{P}\right]-2^{\prime}-$ deoxycytidine $5^{\prime}$-triphosphate and separated them by electrophoresis on a $6.6 \%$ denaturing polyacrylamide gel. We performed haplotype analysis with Cyrillic 2.1 (Cherwell Scientific Publishing, Reading, UK).

\section{DNA sequence analysis}

For mutation analysis of the PDE6A gene, we amplified $100 \mathrm{ng}$ of genomic DNA by PCR under the following 


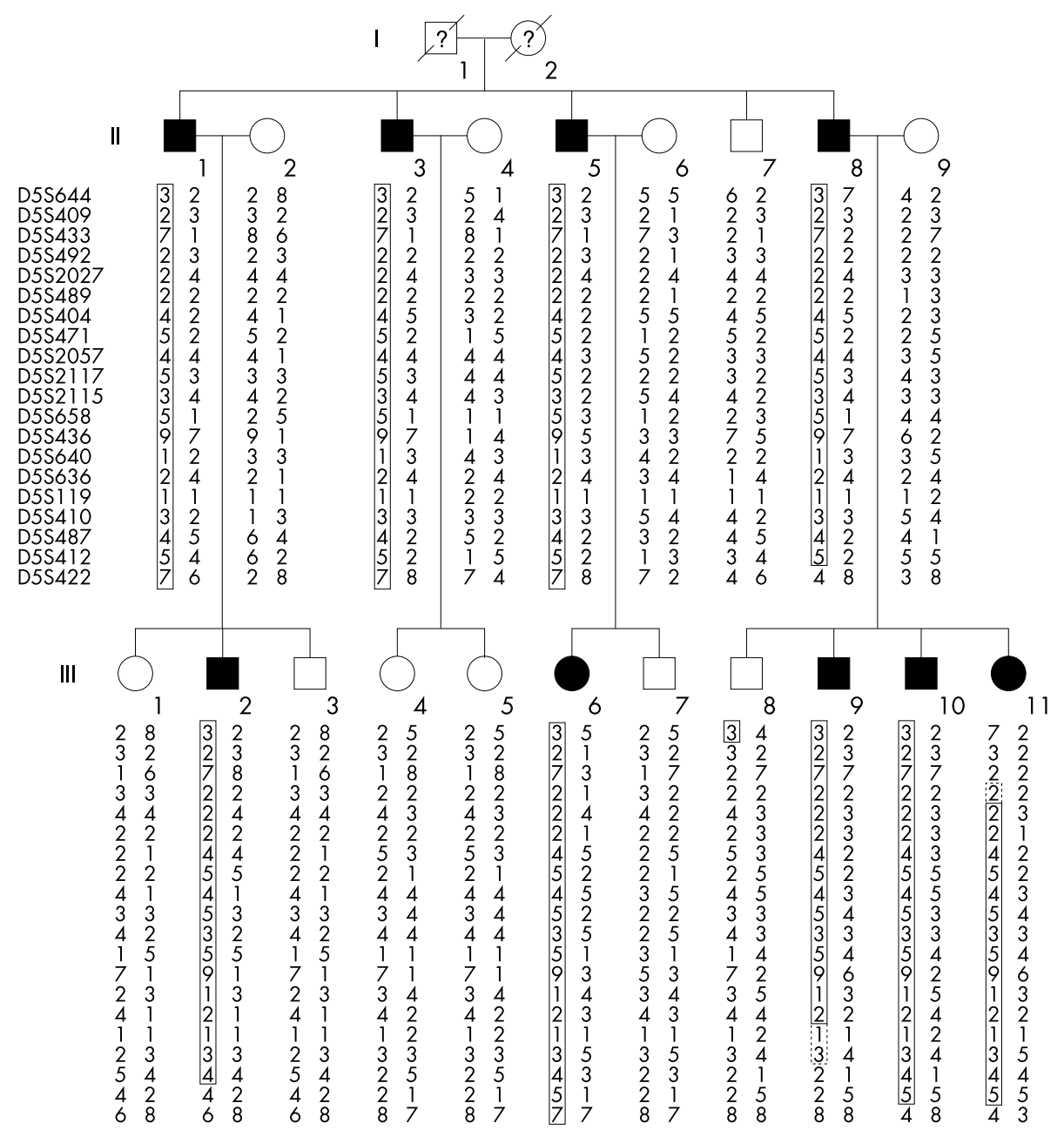

Figure 1 Pedigree of family with butterfly shaped macular dystrophy and haplotypes of microsatellite markers that spanned the linked region on 5q21.2-q33.2. Black symbols denote affected members. Clinical status of the deceased grandparents (I-1 and I-2) is not known. Solid bars denote the haplotype that segregated with disease in the family; dotted bars indicate regions that are not informative.

conditions: initial denaturation for 5 minutes at $95^{\circ} \mathrm{C}$, denaturation for 1 minute at $94^{\circ} \mathrm{C}$, annealing for 1 minute at $55^{\circ} \mathrm{C}$, extension for 1 minute at $72^{\circ} \mathrm{C}$, and final extension for 10 minutes at $72^{\circ} \mathrm{C}$. Primers to amplify each exon and adjacent intron-exon boundaries of the PDE6A gene have been described. ${ }^{19}$ We performed sequencing of PCR products with BigDye Terminator chemistry (Applied Biosystems) on an ABI Prism 3730 or 3100 DNA analyser (Applied Biosystems).

\section{RESULTS AND DISCUSSION}

Previously, we described a Dutch family with butterfly shaped macular dystrophy and excluded involvement of the peripherin/RDS gene; the ROM-1 gene; four genes expressed in cone photoreceptors; all known non-syndromic macular, retinal pigment endothelium, and choroidal dystrophy loci; all known Leber congenital amaurosis loci; and all known non-syndromic congenital and stationary retinal disease loci in this family. ${ }^{12}$ Ophthalmological examination of 21 family members confirmed a definite diagnosis of butterfly shaped macular dystrophy in nine patients and an unaffected status in 11 members (fig 1). Affected patients presented with typical butterfly shaped pigmentations on ophthalmoscopy (fig 2). One member had a slightly diminished electrooculogram but a normal fundus appearance, and she therefore was excluded from the study.

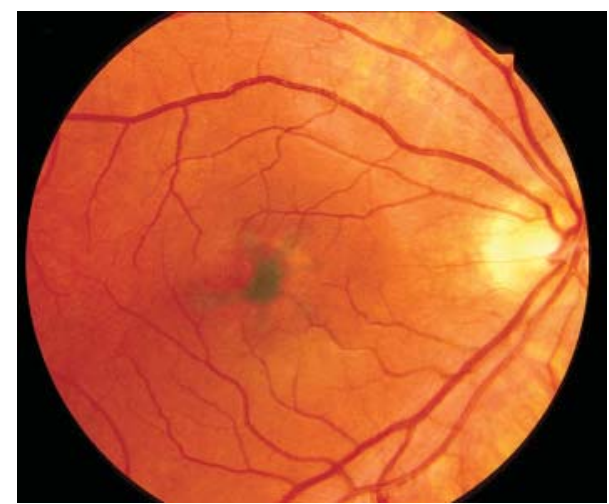

Figure 2 Fundus photograph of patient III- 11 at age 16 years, showing a black butterfly shaped structure.

We performed a genomewide scan to map the locus for butterfly shaped macular dystrophy in this family; we used a set of 400 microsatellite markers with an average spacing of $10 \mathrm{cM}$. Negative or non-significant two point logarithm of odds scores $(<1.0$ at $\theta=0.00)$ were obtained for all tested loci, except for 11 markers on chromosomes 2, 3, 5, and 12 (table 1). A maximum multipoint logarithm of odds score of 


\begin{tabular}{|c|c|c|c|c|c|c|c|c|c|}
\hline \multirow[b]{2}{*}{ Chromosome } & \multirow[b]{2}{*}{ Marker } & \multicolumn{6}{|c|}{ Recombination fraction $(\theta=)$} & \multirow[b]{2}{*}{$Z_{\max }$} & \multirow[b]{2}{*}{$\theta_{\max }$} \\
\hline & & 0.00 & 0.05 & 0.10 & 0.15 & 0.20 & 0.25 & & \\
\hline 2 & D2S2216 & 1.44 & 1.29 & 1.13 & 0.96 & 0.78 & 0.60 & 1.44 & 0.00 \\
\hline 3 & D3S1304 & 1.76 & 1.63 & 1.47 & 1.29 & 1.10 & 0.89 & 1.76 & 0.00 \\
\hline \multirow[t]{10}{*}{5} & D5S424 & 1.44 & 1.29 & 1.13 & 0.96 & 0.79 & 0.61 & 1.44 & 0.00 \\
\hline & D5S641 & -2.61 & 0.37 & 0.62 & 0.67 & 0.64 & 0.54 & 0.67 & 0.15 \\
\hline & D5S428 & -3.39 & -0.46 & -0.19 & -0.07 & -0.02 & 0.00 & 0.00 & 0.25 \\
\hline & D5S644 & -0.21 & 1.45 & 1.60 & 1.56 & 1.42 & 1.22 & 1.60 & 0.10 \\
\hline & D5S433 & -0.35 & 2.02 & 2.00 & 1.84 & 1.61 & 1.34 & 2.02 & 0.05 \\
\hline & D5S2027 & 3.38 & 3.08 & 2.76 & 2.42 & 2.07 & 1.69 & 3.38 & 0.00 \\
\hline & D5S471 & 1.45 & 1.37 & 1.27 & 1.15 & 1.01 & 0.85 & 1.45 & 0.00 \\
\hline & D5S2115 & 3.37 & 3.04 & 2.71 & 2.35 & 1.99 & 1.61 & 3.37 & 0.00 \\
\hline & D5S436 & 3.89 & 3.54 & 3.17 & 2.79 & 2.38 & 1.95 & 3.89 & 0.00 \\
\hline & D5S410 & 1.67 & 1.50 & 1.32 & 1.13 & 0.93 & 0.73 & 1.67 & 0.00 \\
\hline \multirow[t]{5}{*}{12} & D12S351 & 1.46 & 1.74 & 1.76 & 1.67 & 1.50 & 1.27 & 1.76 & 0.10 \\
\hline & D12S346 & 1.46 & 1.74 & 1.76 & 1.67 & 1.50 & 1.27 & 1.76 & 0.10 \\
\hline & D12S78 & 0.22 & 0.69 & 0.87 & 0.91 & 0.87 & 0.76 & 0.91 & 0.15 \\
\hline & D12S79 & 1.52 & 1.68 & 1.66 & 1.56 & 1.39 & 1.19 & 1.68 & 0.05 \\
\hline & D12S86 & -1.92 & 1.13 & 1.27 & 1.24 & 1.13 & 0.97 & 1.27 & 1.10 \\
\hline
\end{tabular}

4.05 was seen for the region on chromosome 5 between markers D5S433 and D5S410.

We constructed haplotypes for the four chromosomal regions. We saw discordance of segregation of the chromosome 2 and 12 haplotypes with the butterfly shaped macular dystrophy phenotype (data not shown). The at risk chromosome 2 haplotype was not seen in one affected patient (III-2), but it was present in two unaffected family members (III-3 and III-8). The at risk chromosome 12 haplotype was present in three unaffected family members (II-7, III-4, and III-7). The regions that surrounded the loci on chromosomes 3 and 5 were saturated with more microsatellite markers, and we constructed haplotypes. The at risk chromosome 3 haplotype was not present in five affected patients (II-8, III-2, III-9, III10 , and III-11), but it was present in five unaffected family members (II-7, III-1, III-3, III-4, and III-7) (data not shown). Haplotypes of the chromosome 5 region showed complete segregation with the butterfly shaped macular dystrophy phenotype. Finemapping of the region with an average marker distance of $3 \mathrm{cM}$ showed that the responsible gene is located on 5q21.2-q33.2 in a $46 \mathrm{cM}(52 \mathrm{Mb})$ interval between markers D5S433 and D5S487 (fig 1).

The interval between markers D5S433 and D5S487 contains more than 450 genes and includes the PDE6A gene that encodes the $\alpha$ subunit of cyclic guanosine $5^{\prime}$ monophosphate phosphodiesterase 6A, a component of the phototransduction cascade. Mutations in the PDE6A gene have been found to cause autosomal recessive retinitis pigmentosa. ${ }^{19}{ }^{20}$ Mutations in the $A B C A 4$ and peripherin/RDS genes cause various retinal dystrophies, including retinitis pigmentosa and macular dystrophy. ${ }^{21-27}$ The PDE6A gene thus was considered to be a candidate gene for butterfly shaped macular dystrophy. We analysed the 22 exons of the PDE6A gene by sequencing in two affected patients (II-1 and II-8) but identified no sequence changes. This does not completely rule out the involvement of PDE6A, however, as larger deletions or insertions may have been missed by PCR based mutation analysis. Apart from PDE6A, no other obvious candidate genes were seen in the $52 \mathrm{Mb}$ interval.

To date, butterfly shaped macular dystrophy has been associated only with mutations in the peripherin/RDS gene. In the family affected by butterfly shaped macular dystrophy described here, we excluded the peripherin/RDS gene and identified a novel locus on 5q21.2-q33.2. Linkage analysis in additional families affected by butterfly shaped macular dystrophy but without mutations in the peripherin/RDS gene may enable a refinement of the critical interval and facilitate the identification of the responsible gene.

\section{ACKNOWLEDGEMENTS}

We thank Bellinda van den Helm for technical assistance.

\section{Authors' affiliations}

A I den Hollander, F F J Kersten, J G A M Heister, C G F de Kovel,

F P M Cremers, Department of Human Genetics, University Medical Center Nijmegen, Nijmegen, Netherlands

J J C van Lith-Verhoeven, A F Deutman, C B Hoyng, Department of Ophthalmology, University Medical Center Nijmegen

Funding. This work was financed by the British Retinitis Pigmentosa Society GR543.

Conflicts of interest: none declared.

Correspondence to: A I den Hollander, Department of Human Genetics, University Medical Center Nijmegen, PO Box 9101, 6500 HB Nijmegen, Netherlands; a.denhollander@antrg.umen.nl

Revised version received 22 March 2004

Accepted for publication 24 March 2004

\section{REFERENCES}

1 Deutman AF, van Blommestein JD, Henkes HE, Waardenburg PJ, Solleveldvan Driest E. Butterfly-shaped pigment dystrophy of the fovea. Arch Ophthalmol 1970;83:558-69.

2 Van Lith-Verhoeven JJC, Cremers FPM, van den Helm B, Hoyng CB, Deutman AF. Genetic heterogeneity of butterfly-shaped pigment dystrophy of the fovea. Mol Vis 2003;9:138-43.

3 Rosenberg T, Klie F. Current trends in newly registered blindness in Denmark. Acta Ophthalmol Scand 1996;74:395-8.

4 Krumpaszky HG, Lüdtke R, Mickler A, Klauss V, Selbmann HK. Blindness incidence in Germany. A population-based study from WürttembergHohenzollern. Ophthalmologica 1999;213:176-82.

5 Feist RM, White MF, Skalka H, Stone EM. Choroidal neovascularization in a patient with adult foveomacular dystrophy and a mutation in the retinal degeneration slow gene (Pro 210 Arg). Am J Ophthalmol 1994; 1 18:259-60.

6 Kim RY, Dollfus H, Keen TJ, Fitzke FW, Arden GB, Bhattacharya SS, Bird AC. Autosomal dominant pattern dystrophy of the retina associated with a 4 -base pair insertion at codon 140 in the peripherin/RDS gene. Arch Ophthalmol 1995:113:451-5

7 Richards SC, Creel DJ. Pattern dystrophy and retinitis pigmentosa caused by a peripherin/RDS mutation. Retina 1995; 15:68-72.

8 Fossarello M, Bertini C, Silvana Galantuomo M Cao A, Serra A, Pirastu M. Deletion in the peripherin/RDS gene in two unrelated Sardinian families with autosomal dominant butterfly-shaped macular dystrophy. Arch Ophthalmol 1996;1 14:448-56. 
9 Nichols BE, Sheffield VC, Vandenburgh K Drack AV, Kimura AE, Stone EM Butterfly-shaped pigment dystrophy of the fovea caused by a point mutation in codon 167 of the RDS gene. Nature Genet 1993;3:202-7.

10 Nichols BE, Drack AV, Vandenburgh K, Kimura AE, Sheffield VC, Stone EM. A 2 base pair deletion in the RDS gene associated with butterfly-shaped pigment dystrophy of the fovea. Hum Mol Genet 1993;2:601-3.

11 Grover S, Fishman GA, Stone EM. Atypical presentation of pattern dystrophy in two families with peripherin/RDS mutations. Ophthalmology 2002; 109: $1110-7$

12 Zhang K, Garibaldi DC, Li Y, Green WR, Zack DJ. Butterfly-shaped pattern dystrophy: A genetic, clinical, and histopathological report. Arch Ophthalmol 2002;120:485-90

13 Miller SA, Dykes DD, Polesky HF. A simple salting out procedure for extracting DNA from human nucleated cells. Nucleic Acids Res 1988;16:1215.

14 van Camp G, Balemans W, Willems PJ. Linkage Designer and Linkage Reporter software for automated gene localization studies. Technical Tips Online 1997; 1:T40013.

15 O'Connell JR, Weeks DE. PedCheck: a program for identification of genotype incompatibilities in linkage analysis. Am J Hum Genet 1998:63:259-66.

16 Lathrop GM, Lalouel J-M. Easy calculations of lod scores and genetic risk on small computers. Am J Hum Genet 1984;36:460-5.

17 Dib C, Faure S, Fizames C, Samson D, Drouot N, Vignal A, Millasseau P, Marc S, Hazan J, Seboun E, Lathrop M, Gyapay G, Morissette J, Weissenbach J. A comprehensive genetic map of the human genome based on 5,264 microsatellites. Nature 1996;380:152-4.

18 Broman KW, Murray JC, Sheffield VC, White RL, Weber JL. Comprehensive human genetic maps: Individual and sex-specific variation in recombination. Am J Hum Genet 1998:63:861-9.

19 Huang SH, Pittler SJ, Huang X, Oliveira L, Berson EL, Dryja TP. Autosomal recessive retinitis pigmentosa caused by mutations in the $\alpha$ subunit of rod cGMP phosphodiesterase. Nature Genet 1995; 11:468-71.
20 Dryia TP, Rucinski DE, Huang Chen S, Berson EL. Frequency of mutations in the gene encoding the $\alpha$ subunit of rod cGMP-phosphodiesterase in autosomal recessive retinitis pigmentosa. Invest Ophthalmol Vis Sci 1999;40:1859-65.

21 Allikmets $R$, Singh $N$, Sun $H$, Shroyer NF, Hutchinson A, Chidambaram A Gerrard B, Baird L, Stauffer D, Peiffer A, Rattner A, Smallwood P, Li Y, Anderson KL, Lewis RA, Nathans J, Leppert M, Dean M, Lupski JR. A photoreceptor cell-specific ATP-binding transporter gene $(A B C R)$ is mutated in recessive Stargardt macular dystrophy. Nature Genet 1997;15:236-46.

22 Cremers FPM, van de Pol TJR, van Driel M, den Hollander Al, van Haren FJJ, Knoers NVAM, Tijmes N, Bergen AAB, Rohrschneider K, Blankenagel A, Pinckers AJL, Deutman AF, Hoyng CB. Autosomal recessive retinitis pigmentosa and cone-rod dystrophy caused by splice site mutations in the Stargardt's disease gene ABCR. Hum Mol Genet 1998;7:355-62.

23 Martinez-Mir A, Paloma E, Allikmets R, Ayuso C, del Rio T, Dean M, Vilageliu L, Gonzàlez-Duarte R, Balcells S. Retinitis pigmentosa caused by a homozygous mutation in the Stargardt disease gene $A B C R$. Nature Genet 1998;18:11-2

24 Dryja TP, Hahn LB, Kajiwara K, Berson EL. Dominant and digenic mutations in the peripherin/RDS and ROMI genes in retinitis pigmentosa. Invest Ophthalmol Vis Sci 1997;38:1972-82.

25 Kajiwara K, Hahn LB, Mukai S, Travis GH, Berson EL, Dryja TP. Mutations in the human retinal degeneration slow gene in autosomal dominant retinitis pigmentosa. Nature 1991;354:480-3.

26 Felbor $\mathrm{U}$, Schilling $\mathrm{H}$, Weber BH. Adult vitelliform macular dystrophy is frequently associated with mutations in the peripherin/RDS gene. Hum Mutat 1997; 10:301-9.

27 Wells J, Wroblewski J, Keen J, Inglehearn C, Jubb C, Eckstein A, Jay M, Arden J, Bhattacharya S, Fitzke F, Bird A. Mutations in the human retina degeneration slow (RDS) gene can cause either retinitis pigmentosa or macular dystrophy. Nature Genet 1993;3:213-8. 